\title{
An Actuarial Analysis of the Payout Options in Nigeria's Contributory Pension Scheme
}

\author{
Ade Ibiwoye \\ Department of Actuarial Science \& Insurance, Faculty of Business Administration \\ University of Lagos, Nigeria \\ Tel: 234-80-3307-8121_E-mail: adeibiwoye@yahoo.com \\ Lukman Ajijola (Corresponding author) \\ Department of Actuarial Science \& Insurance, Faculty of Business Administration \\ University of Lagos, Nigeria \\ Tel: 234-80-5581-4056_E-mail: ajiluqman@yahoo.com; lajijola@unilag.edu.ng
}

\author{
Received: July 18, 2012 \\ Accepted: September 14, 2012 \\ Online Published: October 26, 2012 \\ doi:10.5430/ijba.v3n6p45 \\ URL: http://dx.doi.org/10.5430/ijba.v3n6p45
}

\begin{abstract}
Several years after the reform of the pension scheme in Nigeria, there is still trepidation about the success of the scheme. A particularly knotty issue is the mode of collecting benefits after retirement. It would seem that many retirees prefer programmed withdrawal to annuities without considering their individual circumstances. This portends a dangerous trend for the pension scheme. In this paper we attempt to bring in the individual characteristics into the decision making process by comparing the replacement rates of a potential retiree under the programmed withdrawal with that of life annuity. Our study reveals that life annuity may be the future direction if the scheme is not to face the same fate as the previous defined benefit scheme.
\end{abstract}

Keywords: Defined contribution plan, Payout option, Replacement rate, Programmed withdrawal, Life annuity

\section{Introduction}

Nigeria replaced its erstwhile unfunded defined benefit scheme in the public sector with a defined contribution scheme in 2004. The sheer size of the public sector workforce in Nigeria had made it difficult for the government to pay its workers their salary, let alone adequately meet its pension commitments (Lakemfa, 2004). The crisis generated by this development had necessitated the reform undertaken by government. The new scheme applies to both the public and private sectors. It is aimed, among other objectives, at ensuring that every retiree receives his benefits as and when due, unlike what was experienced by retirees under the old scheme.

The new scheme differs from the defined benefit scheme both at the accumulation phase and the decumulation, or pay-out, stage. In the new dispensation both employers and employees are required to contribute to the fund. At the decumulation stage Section 4(1) of the Pension Reform Act (PRA), 2004 clearly spelt out the method for disbursing benefits. It provides that a holder of a retirement savings account upon retirement shall have a choice between programmed withdrawal, calculated on the basis of an expected life span, or an annuity for life purchased from a life insurance company licensed by the National Insurance Commission. Neither of the stipulated methods is risk-free. With programmed withdrawal if the retiree lives longer than what had been projected, the capital may be completely exhausted while the retiree is still alive (Antolin, Pugh and Stewart, 2008), old-age poverty could set in and that might defeat the essence of the pension scheme that targets making retirees get regular income till death. In the case of the annuity alternative the risk that the annuitant may die shortly after he has collected a few income payments makes this option rather unattractive. In particular, the annuity market is still relatively new in Nigeria (PenCom, 2010).

It would appear, then, that in the absence of any basis for making an informed choice, many retirees have, irrespective of their individual circumstances, opted for either programmed withdrawal when, indeed, they should have chosen life annuity or vice versa. A first quarter report by the National Pension Commission (PenCom, 2011) 
shows that as at the end of February 2011, retirees that migrated to the new scheme in 2004 had taken a total of 35,202 programmed withdrawal products, while annuity policies recorded only 128 .

Replacement rates have been developed with a view to shedding more light on the adequacy of pensions and in particular, to measuring the extent to which pension systems enable workers to preserve their previous living standard when moving from employment to retirement (www.aon.com/retire).This means that replacement rates show the level of pensions as a percentage of previous individual earnings at the moment of take-up of pensions. This paper compares the replacement rate of a potential retiree when the retiree chooses programmed withdrawal with the rate if life annuity after retirement were chosen in order to know the status of potential retirees after retirement.

The rest of the paper is organized as follows: Section 2 reviews relevant literature. Section 3 discusses data and methodology. Section 4 discusses results while Section 5 concludes.

\section{Literature Review}

The life of a pension fund has two distinct phases: accumulation and decumulation. In the first contributions are made while in the other benefits are collected. Kocken and Potters (2011) posited that pension fund is extremely fragile in the decumulation phase. In it, the fund is much less likely to survive any shock that puts it into deficit. They concluded that once a pension fund enters the decumulation phase, market volatility is dangerous even with long term positive returns. James and Vittas (1999) observed that the underdevelopment of voluntary annuity markets is only partly explained by adverse selection. They argued that the provision of annuities and other benefits during the decumulation phase of DC pension plans raises major policy issues and concluded that as the private markets for annuities and disability benefits are not well developed, even in the most advanced OECD countries, the resolution of these issues is likely to be a gradual process, with both countries and markets learning through experience.

Blake, Cairns, and Dowd (2009) posited that we can think of defined contribution (DC) plan as having three stages: initial marketing, accumulation, and decumulation. They reasoned that there is some disconnect among these three stages in a DC plan because the three stages are arranged by three different and independent groups of people. Another reason for the disconnect, they added, is that the customer, the potential pension plan member, generally has a very poor understanding of each stage and of the resources required and risks involved in the delivery of an adequate pension. Sadly, the customer, then, often buys into a pension plan with very little idea of how much retirement income the plan will eventually provide.

Although works on the decumulation phase of the contributory pension scheme is extensive many of the previous studies failed to incorporate the choice of pay-out option and the impact of inflation and longevity risk of retirement income on the plan. Horneff et al. (2007) compared different standardized payout strategies to show how people can optimize their retirement portfolios. They concluded that annuities are attractive as a stand-alone product when the retiree has sufficiently high risk aversion and lacks a bequest motive. Withdrawal plans dominate annuities for low/moderate risk preferences, because the retiree can gain by investing in the capital market. An innovation worth noting is the introduction of fixed and variable annuities by Chai et al. (2009) in which they showed that variable annuities generate higher levels of retirement income flows compared to fixed annuities. In a related study, Antolin (2008) assessed how countries' pension arrangements and regulation shape the appropriate structure and flexibility of retirement payout options.

Maiturare and Adeyeye (2010) examined the effect of longevity risk on retirement income by focusing on the mode of utilizing pension funds at retirement and concluded that the life insurance industry may have obvious interest in helping individuals' drawdown their retirement assets in an orderly way, but it is not capable on its own, to address the challenge posed by longevity. Consequently, they recommended that government should create incentives for all employers to introduce more lifetime income options in addition to the one available under the present dDefined Contribution plan.

Antolin, Payet and Yermo (2010) assessed the relative performance of different investment strategies for different structures of the payout phase. In particular, they looked at whether the specific glide-path of life investment strategies and the introduction of dynamic features in the design of default investment strategies affect significantly retirement income outcomes. An interesting conclusion from their study is that there is no "one-size-fits-all" default investment option. They applied both a stochastic and historical model to assess the suitability of different default investment strategies from the perspective of the regulator taking into account both the accumulation and the payout phases. By using replacement rates as the main measure to assess the risk-return trade-off of different default 
investment strategies they introduced different options for the payout phase of pensions (constant life annuity, inflation-linked life annuity, fixed programmed withdrawal, variable programmed withdrawal and a combined arrangement mixing a programmed withdrawal with a deferred life annuity).

Works that deal with the financial risk in the distribution phase of DC pension plans include Albrecht and Maurer (2002), Blake, Cairns, and Dowd (2003), Gerrard, Haberman, and Vigna (2004), Gerrard et al. (2004), Kapur and Orszag (1999), Khorasanee (1996), Milevsky (2001), and Milevsky and Young (2002).

\section{Methodology}

In order to compare the replacement rates under the two options available under the PRA, 2004 effectively, there is need to calculate the accumulated balance in a participant's retirement savings account. Following Iyer (1999) we introduce a parameter $\gamma^{*}$ which represents the force of growth of the salary of a participant, assumed constant throughout the participant's career. It represents the combined effect of general salary escalation $(\gamma)$ and progression of the member's salary due to advancing seniority (the salary scale effect). Thus $\gamma^{*}$ would generally be greater than $\gamma$.

Taking the starting annual salary as one monetary unit and the contribution density as 100 per cent, the accumulated balance after a contributory career of $\mathrm{n}$ years will be given by

$$
\pi \int_{0}^{n} e^{\gamma^{*} t} e^{\delta(n-t)} d t=\pi e^{n \delta} \overline{\bar{s}} \frac{\left(\gamma^{*}-\delta\right)}{n}=\pi e^{n \gamma^{*}} \bar{a} \frac{\left(\gamma^{*}-\delta\right)}{n\rceil}
$$

The accumulated balance can also be expressed as

$$
\pi e^{n \delta} \bar{a}_{\bar{n}\rceil}^{\left(\delta-\gamma^{*}\right)}=\pi e^{n \gamma^{*}} \bar{s}_{n \overline{1}}^{\left(\delta-\gamma^{*}\right)}
$$

where $\pi=$ the contribution rate.

$\bar{s} \frac{\left(\gamma^{*}-\delta\right)}{n !}$ accumulated amount of the contributions for $n$ years computed at a rate of $\gamma^{*}-\delta$

$\bar{s} \bar{n} \overline{\left(\delta-\gamma^{*}\right)}=$ accumulated amount of the contributions for $n$ years computed at a rate of $\delta-\gamma^{*}$

$\bar{a} \frac{\left(\gamma^{*}-\delta\right)}{n !}=$ present value of the contributions for $n$ years computed at a rate of $\gamma^{*}-\delta$

$\bar{a} \frac{\left(\delta-\gamma^{*}\right)}{n !}=$ present value of the contributions for $n$ years computed at a rate of $\delta-\gamma^{*}$

Mathematically, all four expressions are acceptable although (1) may be preferred when $\gamma^{*}$ is greater than $\delta$ and (2) in the case where $\delta>\gamma^{*}$. This is however, only a matter of presentation and both forms $\delta-\gamma^{*}$ and $\gamma^{*}-\delta$ are used in the following development.

It is useful to relate the accumulated balance to the final annual salary or final emolument as the case may be, $e^{n \gamma^{*}}$, which represents the member's earning power just before retirement. This gives the following result for the relative accumulated balance, that is, the balance as a multiple of the final salary:

$$
\pi \bar{a} \frac{\left(\gamma^{*}-\delta\right)}{n !}
$$

This shows that the relative accumulated balance depends only on the difference $\gamma^{*}-\delta$. The lower this difference (i.e. the higher $\delta$ relative to $\gamma^{*}$ ), the higher the relative accumulated balance.

The total nominal amount of the contributions (excluding interest) is given by

$$
\pi \int_{0}^{n} e^{\gamma^{*} t} d t=\pi e^{n \gamma^{*}} \bar{a} \frac{\left(\gamma^{*}\right)}{n]}
$$

By dividing (2) by (4), the accumulated balance can be expressed as a multiple of the sum of the contributions, which shows the relative importance of the interest element in the balance

$$
\frac{\pi e^{n \gamma^{*}} \bar{a} \frac{\left(\gamma^{*}-\delta\right)}{n !}}{\pi e^{n \gamma^{*}} \bar{a} \frac{\left(\gamma^{*}\right)}{n !}}=\frac{\bar{a} \frac{\left(\gamma^{*}-\delta\right)}{\bar{n} \mid}}{\bar{a} \frac{\left(\gamma^{*}\right)}{n !}}
$$

Further to Iyer's (1999) proposition, if the balance is converted into an annuity at, say, age $x$, the replacement rate, that is, the initial amount of the annuity as a percentage of the terminal salary, will be obtained by dividing (3) by the appropriate annuity factor. The simplest case is where the annuity is payable for $m$ years certain and is not indexed. 
The replacement rate is then given by $\pi \frac{\left.\bar{a} \frac{\left(\gamma^{*}\right.}{n !} \delta\right)}{\bar{a}_{\bar{m}}^{(\delta)}}$. If the annuity is to be indexed with force $\beta$, then the annuity factor in the denominator should refer to force $(\delta-\beta)$,which will lead to a lower replacement rate. This illustrates an important difference between defined contribution and defined benefit schemes; in the latter schemes, indexation of the pension, if provided for, generally forms part of the benefit package, whereas in the former, indexation has to be traded off against a lower replacement rate.

The balance can be used to purchase life annuity by using the annuity factor $\bar{a}_{x}^{(\delta-\beta)}$.In that case the replacement rate becomes $\pi \frac{\bar{a} \frac{\left(\gamma^{*}-\delta\right)}{n !}}{\bar{a}_{x}^{(\delta-\beta)}}$. The replacement rate will increase if either $\gamma^{*}-\delta$ decreases or $\delta-\beta$ increases. Thus a higher rate of interest relative to the rate of salary progression and/or of indexation increases the replacement rate.

\subsection{Model Application}

We apply the model to the Consolidated University Academics Salary Structure (CONUASS II) of the Nigerian universities. We make the following assumptions:

- entering age is 30 (to allow for the fairly long gestation period it takes a fresh M.Sc. graduate to opt for University teaching rather than employment in the private sector)

- the Assumed Investment Return $(A I R)=i=12 \%$ which implies that force of interest $\delta=\ln (1.12)=$ 0.113329. (see http://www.nigerianbestforum.com/generaltopics/?p=110098 which states that the return on the investment of the pension fund for the four years 2007, 2008, 2009 and 2010 are 19.37 per cent, 0.34 per cent, 11.41 per cent and 11.64 per cent respectively.)

- there are no taxes, inflation, expenses, and allowances for profit in the pricing of the financial assets and the management of the DC plan.

- the only source of income after retirement of the member is pension income

- the life tables used for determination of life expectancy and the life annuity value is from http://www.ssa.gov/OACT/STATS/table4c6.html

For the retirement age $r$, we adopt section 4(1) (a) and (b) of the Pension Reform Act, 2004, which provides that the holder of a retirement savings account, upon retirement or attaining the age of 50 years, whichever is later, shall utilise the balance standing to the credit of his retirement savings account for (a) programmed monthly or quarterly withdrawals calculated on the basis of an expected life span or (b)annuity for life purchased from a life insurance company licensed by the National Insurance Commission with monthly or quarterly payments.

We carried out scenario testing for academics who retired at age 50 and 65. Also, we took into consideration, the recent, 2009, agreement between government and the academic trade union, ASUU that has fixed the new retirement age of Professors at 70 years.

The combined contribution of both the employer and the employee is $\pi=15 \%$ of employee's basic salary (as stipulated by the Pension Reform Act, 2004) and the contribution is remitted into each individual Retirement Saving Account (RSA) as at when due.

We derive $\gamma^{*}$ which represents the force of growth of the salary of a participant by equating $A E_{g} e^{\gamma^{*}}=A E_{p} \Rightarrow \gamma^{*}=$ $\ln \frac{A E_{p}}{A E_{g}}$, where $A E_{p}$ is the Average Emolument of a Professor and $A E_{g}$ is the Average Emolument of a Graduate Assistant. Emolument consists of Basic Salary, Peculiar Allowance and Rent Allowance. The value is 4\% (that is, $\left.\gamma^{*}=4 \%\right)$

\section{Results and Discussion}

Under the defined contribution plan, the joint employee and employer contributions made on behalf of each participant sum up to $15 \%$. The actuarial problem then is to calculate the actuarial present value (APV) of benefit that will produce an equal actuarial present value (APV) as the contribution, based on the equivalence principle (Bowers et al. 1997). In our study, we have used the Consolidated University Academics Salary Structure II (CONUASS II) 
to calculate the APV of the accumulated amount in the retirement saving account (RSA) of each academic staff. We have used earliest retirement age of 50 years and mandatory retirement age of 65 for non-professorial cadre and 70 for those in professorial cadre (See Table 1). The resulting replacement rates at the specified retirement ages are then calculated both under programmed withdrawal and life annuity.

From Figures 1 and 2, it can be seen that retiring at age 50 will provide a maximum of $2 \%$ retirement rate (that is $2 \%$ of the earnings of an academics before his or her retirement) for a retired academics who choose programmed withdrawal while it will be a maximum of $9 \%$ for those who choose life annuity. This is a far cry from the proposed two-third replacement rates suggested by MacDonald and Cairns (2006) which is approximately $67 \%$ of the earning before retirement.

The case is a little bit different for those who retired at age 65. From Figures 3 and 4, it could be seen that the maximum replacement rate ranges between $66 \%$ and $68 \%$ for those who choose life annuity while it is only between $26 \%$ and $27 \%$ for those who choose programmed withdrawal.

Replacement rates for professors who choose to retire at age 70, and opt for programmed withdrawal will not meet up with the required two-third. The maximum he or she will get is $60 \%$ replacement rate which largely depends on the unrealistic assumption of a participant entering into the workforce as a professor, working for 40 years and retiring as a professor (see Figure 5). However, for those who entered at least as senior lecturer, put in 40 years of service and opted for life annuity, they will get a replacement rates greater than or equal to $92 \%$ but less than $133 \%$, provided they retired as professor (see Figure 6).

\section{Conclusion and Recommendation}

This study has shown how a participant in the DC pension plan instituted by Nigeria's government in 2004 can make appropriate choice between programmed withdrawal and a life annuity using the academic salary scale as illustration. It revealed that with the present salary structure for the academics in Nigerian universities, retiring early cannot guarantee appropriate replacement rate for the retiree.

Programmed withdrawal is financially uncomplicated, and there is no cross-subsidy from those who live for only a short time in retirement to those who live longer than the expected average. It thus seems to address the basic bequest motive and attempt to produce relatively stable annual income for the lifetime of the retiree. Notwithstanding, there are still many variations within this scheme with the main disadvantage of programmed withdrawals being the risk that the capital will be completely exhausted while the retiree is still alive. Life annuity, on the other hand, has the advantage that payments are made for the entire lifetime of the retiree and therefore retirees are protected from longevity risk. In this regard, life annuity appears to be superior to programmed withdrawal.

It would appear that life annuity is the future direction for every employee, since with programmed withdrawal the retiree may be taking the risks on himself/herself.The amount and duration of programmed withdrawals are generally calculated on the basis of average life expectancies, so an individual retiree can easily outlive these averages. Even where the payments are recalculated each year based on the projected future life expectancy of the retiree and the declining group of his/her surviving cohorts, the capital to be re-spread can eventually decline to such a level that the adjusted periodic payments will be correspondingly unattractive. It is also generally argued that the costs of administering a programmed withdrawal and more actively investing the assets are higher than the expense loadings in a life annuity contract (Antolin, Pugh and Stewart, 2008).

\section{References}

Albrecht, P., \& Maurer R. (2002). Self-annuitization, Consumption Shortfall in Retirement and AssetAllocation: The Annuity Benchmark. Journal of Pension Economics and Finance, 1, 269-88.

Antolin P. (2008). Policy Options for the Payout Phase.OECD Working paper on Insurance and Private Pensions, No. 25, September 2008.

Antolin, P., Payet, S., \&Yermo, J. (2010). Assessing Default Investment Strategies in Defined Contribution Pension plans. OECD Journal: Financial Market Trends, 2010(1), (C) OECD 2010.

Antolin, P., Pugh C., \& Stewart F. (2008). Forms of Benefit Payment at Retirement. OECD Working Paperson Insurance and Private Pensions, No. 26, OECD publishing, (C) OECD. http://dx.doi.org/10.1787/238013082545

Blake, D., Cairns, A. J. G., \& Dowd, K. (2003). PensionMetrics 2: Stochastic Pension Plan Design during the Distribution Phase. Insurance: Mathematics and Economics, 33, 29-47. 
Blake, D., Cairns, A. J. G., \& Dowd, K. (2009). Designing a Defined-Contribution Plan: What to Learn from Aircraft Designers. Financial Analysts Journal, 65(1), (O2009 CFA Institute.

Bowers, Newton L. Jr., Hans U.Gerber, James C. Hickman, Donald A. Jones, \& Cecil J. Nesbitt. (1997). The Society of Actuaries. Schaumburg, Illinois.

Chai, J., Horneff, W., Maurer, R., \& Mitchell, O.S. (2009). Extending Life Cycle Models of Optimal Portfolio Choice Integrating Flexible Work, Endogenous Retirement, and Investment Decisions with lifetime Payouts. NBER Working Paper Series, No 15079.

Gerrard, R., Haberman, S., \& Vigna, E. (2004). Optimal Investment Choices post Retirement in a Defined Contribution Pension Scheme. Insurance: Mathematics and Economics, 35, 321-342.

Gerrard, R., Haberman, S., HØjgaard, B., \& Vigna E. (2004). The Income Drawdown: Option Quadratic Loss. Actuarial Research Paper No. 155, Cass Business School, London.

Horneff, W. J., Maurer, R. H., Mitchell, O. S., \& Dus, I. (2007). Following the Rules: Integrating Asset Allocation and Annuitization in Retirement Portfolios. Insurance: Mathematics and Economics, 42, 396-408.

Iyer, S. (1999). Actuarial Mathematics of Social Security Pensions. A Joint Technical Publication of the International Labour Office (ILO) and the International Social Security Association (ISSA), Geneva.

James, E., \& Vittas D. (1999). The Decumulation (Payout) Phase of Defined Contribution Pillars: Policy Issues in the Provision of Annuities and Other Benefits. [Online] Available: http://elibrary.worldbank.org/content/workingpaper/10.1596/1813-9450-2464;

http://elibrary.worldbank.org/docserver/download/2464.pdf?

Kapur, S., \& Orszag, J. M. (1999). A Portfolio Approach to Investment and Annuitization during Retirement. InProceedings of the Third International Congress on Insurance. Mathematics and Economics, London.

Khorasanee, M. Z. (1996). Annuity Choices for Pensioners. Journal of Actuarial Practice, 4, 229-255.

Khorasanee, M. Z. (1998). Deterministic Modelling of Defined Contribution Pension Funds. North American Actuarial Journal, 1, 83-103.

Kocken, T., \& Potters, J. (2011). Managing Risk Vital for Mature Pension Plans-Pension and Investments. [Online] Available: http:/www.pionline.com/article/20110530/PRINTSUB/305309998 (September 4, 2012)

Lakemfa, O. (2004). Briefing Paper at the National Workshop on the New Pension Act, Its Implications and the Challenges for Organized Labour (July 17, 2004). [Online] Available: http://www.nlcng.org/July2004/pensionworkshop.htm (May 12, 2012)

MacDonald, B. J., \& Cairns, A. J. (2006). The Impact of DC Pension Systems on Population Dynamics. North American Actuarial Journal. [Online] Available: www.soa.org/library/journals/north-american-actuarial. ../naaj0701_02.pdf

Maiturare, M., \& Adeyele, J. S. (2010). Pension Benefits and Longevity Risks of the Nigerian Baby Boomers. Journal of Emerging Trends in Economics and Management Sciences (JETEMS), 1(2), 81-89® Scholarlink Research Institute Journals, 2010. [Online] Available: jetems.scholarlinkresearch.org

Milevsky, M. A. (2001). Optimal Annuitization Policies: Analysis of the Options. North American Actuarial Journal 5, 57-69.

Milevsky, M. A., \& Young V. R. (2002). Optimal Asset Allocation and the Real Option to Delay Annuitization: It's Not Now-or-Never, Working paper. In Proceedings of the 8th International Congress on Insurance: Mathematics and Economics, Rome.

National Pension Commission. (2010). Annual Report, Federal Government Press Lagos. [Online] Available: http://www.pencom.gov.ng/download/reports/2010_Annual_Report.pdf (September 4, 2012)

National Pension Commission, Pension Industry Quarterly Review First Quarter. (2011). Federal Government Press Lagos. [Online] Available: http://www.pencom.gov.ng/download/reports/PenCom_First_Quarter_Report_2011.pdf

Pension Reform Act No 2. (2004). Federal Republic of Nigeria Official Gazette. Lagos: Federal Government Press.

[Online] Available: www.aon.com/retire (June 29, 2012)

[Online] Available: http://www.ssa.gov/OACT/STATS/table4c6.html (June 29, 2012)

[Online] Available: http://www.nigerianbestforum.com/generaltopics/?p=110098 (June 29, 2012) 
[Online]

Available:

http://businessdayonline.com/NG/index.php/banking-a-finance/28880-at-last-retirees-embrace-annuity-think-longer-1 ife-in-retirement (June 29, 2012)

Table 1. Descriptive statistics and other calculations

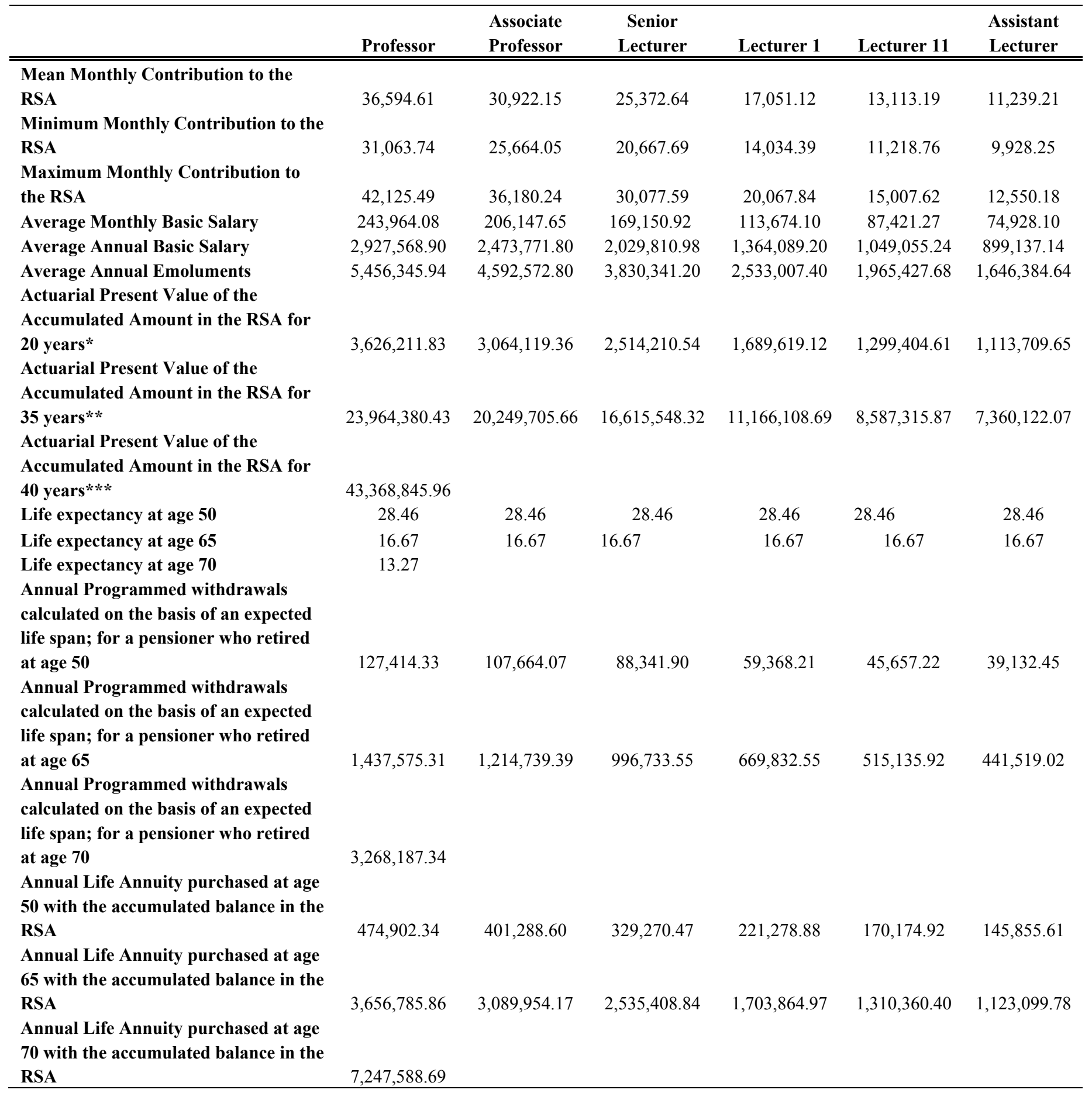

*APV of Accumulated balance for Academics who entered at age 30 and retired at age 50

** APV of Accumulated balance for Academics who entered at age 30 and retired at age 65

*** APV of Accumulated balance for Professors who entered at age 30 and retired at age 70 


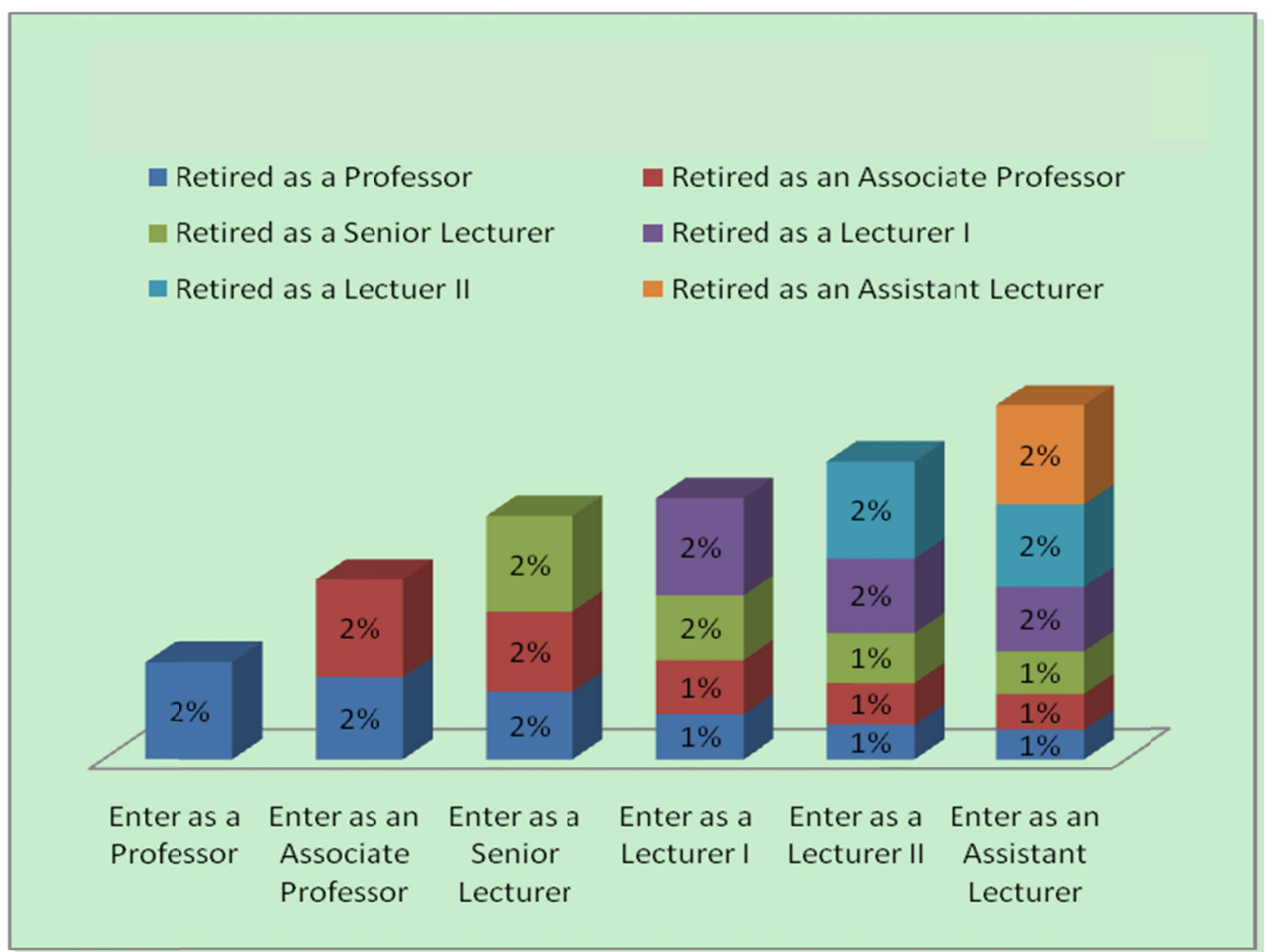

Figure 1. Replacement rates of academics who choose programmed withdrawal and retire at age 50

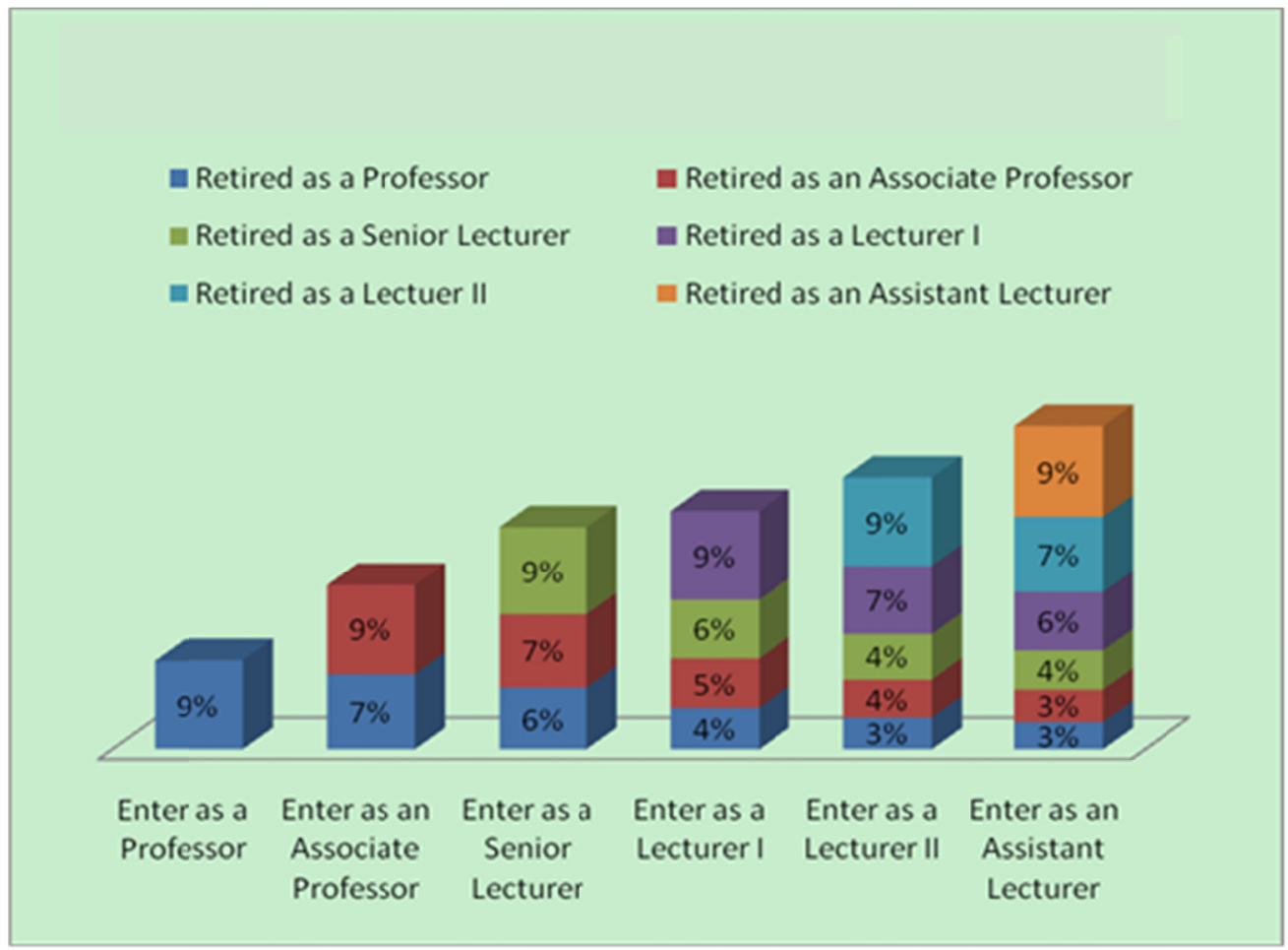

Figure 2. Replacement rates for academics who chose life annuity and retired at age 50 


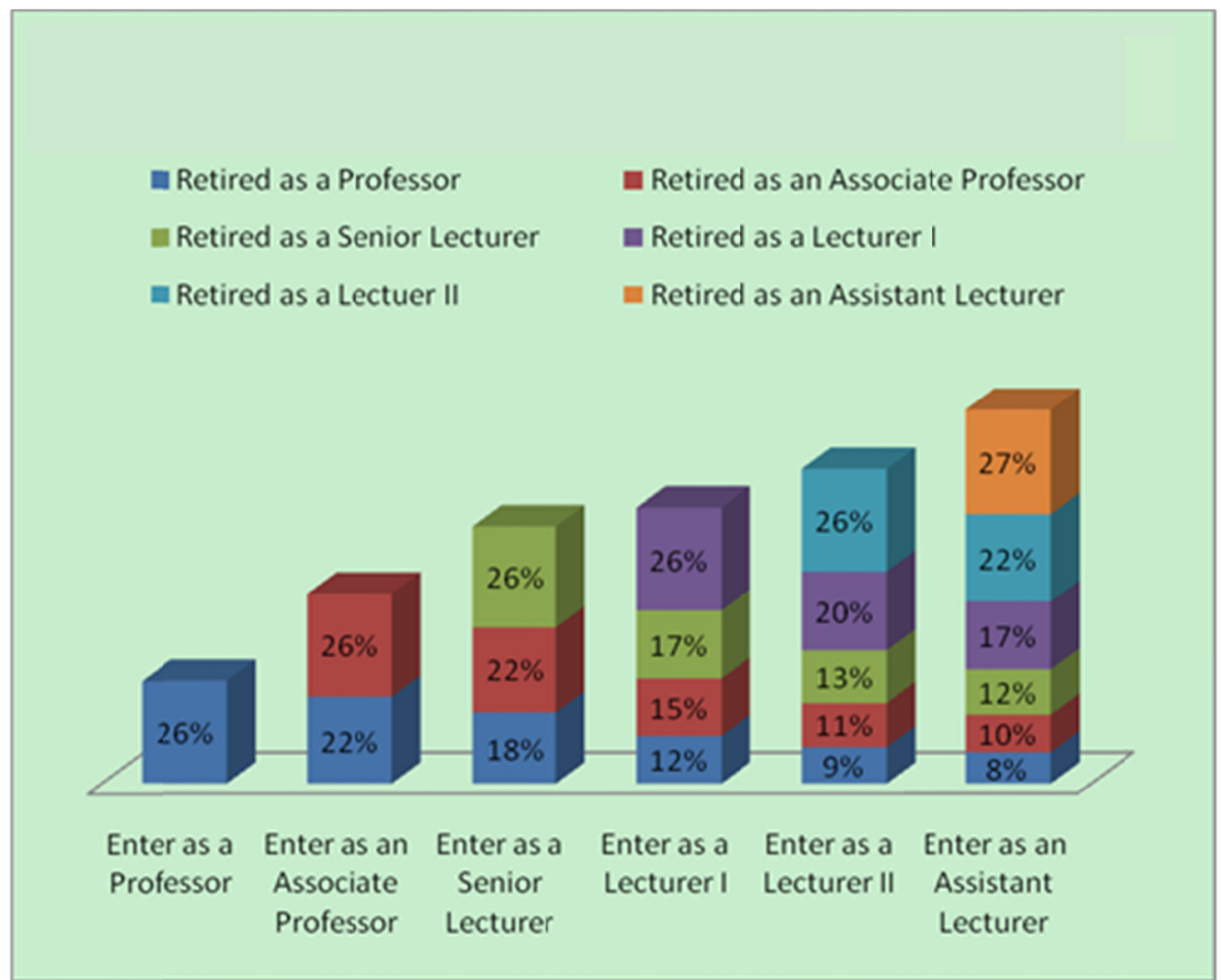

Figure 3. Replacement rates for academics who chose programmed withdrawal and retire at age 65

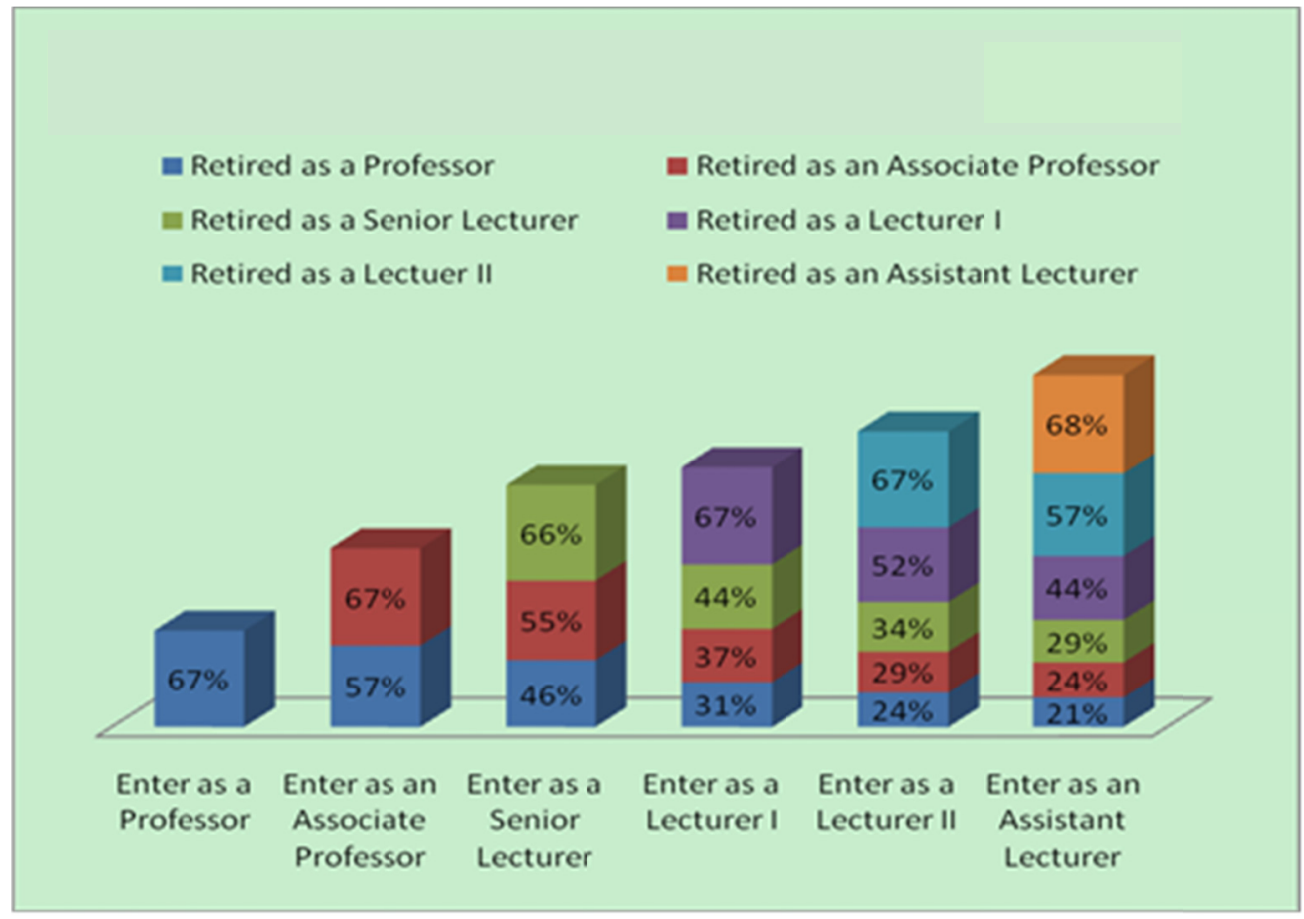

Figure 4. Replacement rates for academics who chose life annuity and retired at age 65 


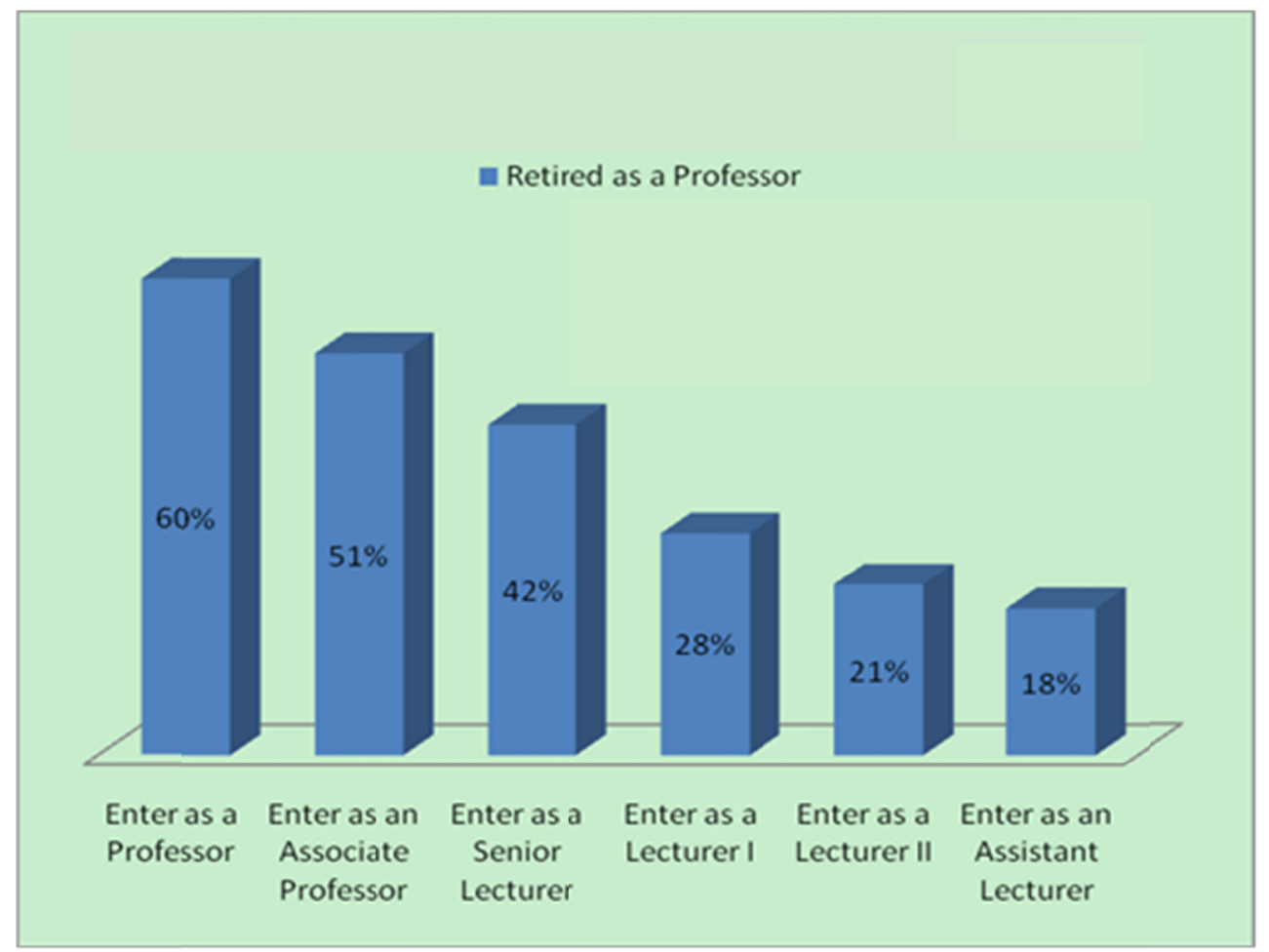

Figure 5. Replacement rates for professor who chose programmed withdrawal and retired at age 70

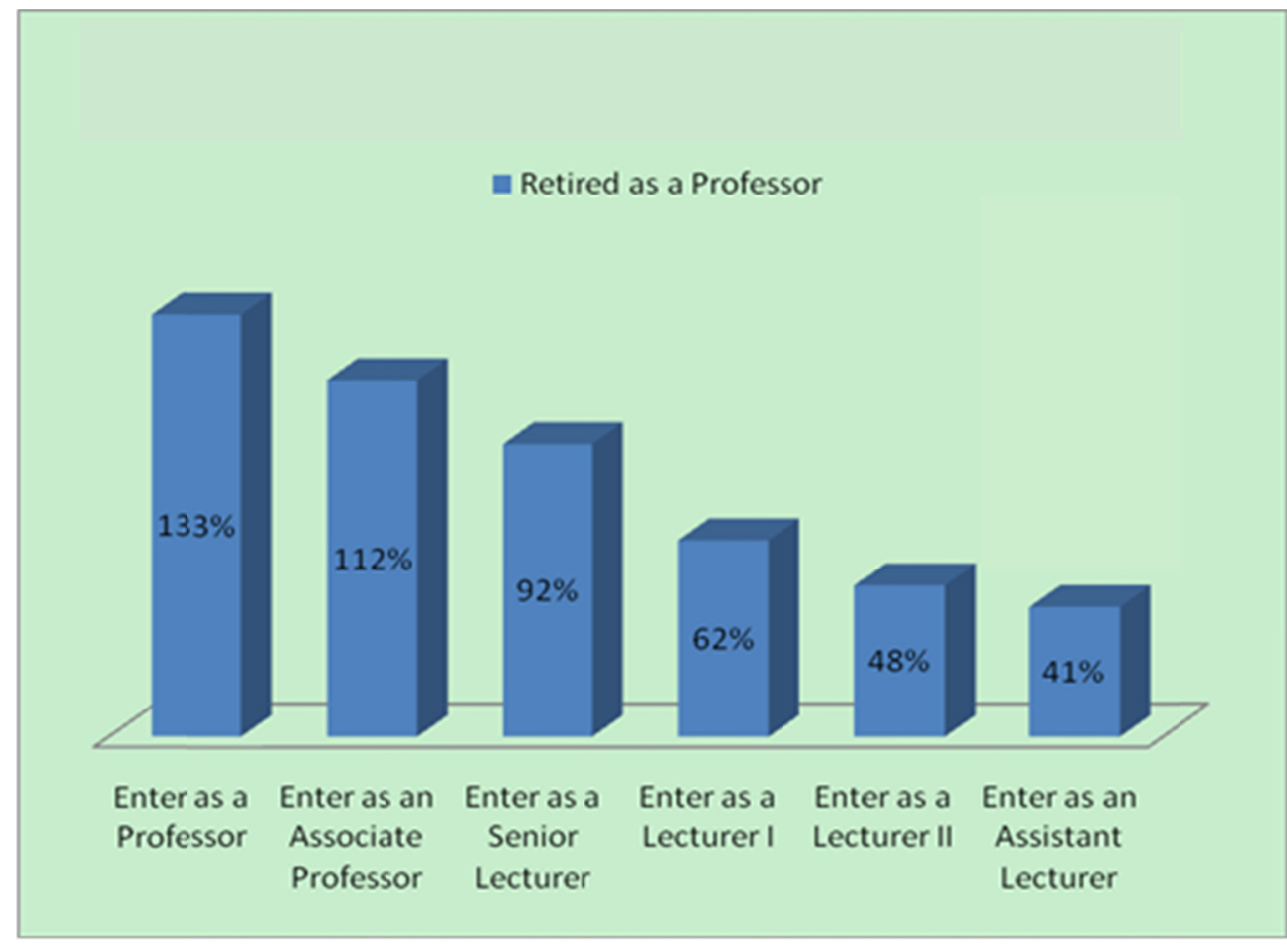

Figure 6. Replacement rates for a professor who chooses life annuity and retires at age 70 